\title{
Study on trade openness of China to Thailand $A$ case study of goods trade
}

\author{
Ying Li \\ International Business School \\ Yunnan University of Finance and Economics \\ Kunming, China \\ 705515930@qq.com
}

Chao $\mathrm{Fu}^{*}$

International Business School

\author{
Yunnan University of Finance and Economics \\ Kunming, China \\ 1905821562@qq.com
}

Jiachen Liu

International Business School

Yunnan University of Finance and Economics

Kunming, China

534623720@qq.com

\begin{abstract}
The Belt and Road", bilateral trade of China and Thailand has rapid developed. Trade openness of China to Thailand also showed a significant change. The article uses 2005-2014 cargo trade volume between China and Thailand, China's GDP as well as Thailand's GDP, quantitative analysis of China to Thailand development status of cargo trade openness. We analyze the influence of China and Thailand cargo trade openness on the basis from the exchange rate of RMB and the Thai baht, the level of the trade facilitation and the trade policy. Then we give the corresponding suggestions.
\end{abstract}

Keywords-China-Thailand; trade openness; trade facilitation; trade policy

\section{INTRODUCTION}

"The Belt and Road" is the "Silk Road Economic Belt" and "21st Century Maritime Silk Road" for short. It will fully rely on the existing bilateral and multilateral mechanisms between China and the relevant countries, with the existing and effective regional cooperation platform. It is that China enters the new normal to promote sustainable economic development of the new opening-up strategy. Through Maritime Silk Road economic belt gradually radiates to South Asia and Africa, it is conducive to the formation of new trade routes to Europe and Asia and the economic development belt. At the same time, it can promote the Middle Western areas of China to speed up the reform and opening, promote the transformation and upgrading and open up of foreign investment. It can also increase the intensity of economic and trade cooperation and promote economic development. Thailand, as the core zone of the ASEAN countries, is the logistics, trade and financial center of ASEAN. It is an important station of the Maritime Silk Road. In order to play a special location advantage, the Thailand government was determined the border special economic zone in 2014. In the policy support, the Thailand's Ministry of Finance as the border special economic zone has been determined, and it is specific responsible of the organization, then we will develop different policy support according to the different special areas.
In cooperation with neighboring countries, the Thailand Ministry of Foreign Affairs will provide support to discuss cooperation with neighboring countries, and coordinate bilateral infrastructure construction pace to realize the maximization of mutual benefit. Therefore, it can be said that the Thailand government's the border economic zone strategy and the strategy of "The Belt and Road" presented by China is highly fit. In summary, the study of trade openness in China and Thailand, and it will help to deepen economic cooperation between China and Thailand. At the same time, by studying the experience of Sino-Thai trade openness, it can provide theoretical reference for the implementation of the "Chinese Belt and Road" strategy. Based on this result, the article first makes a quantitative analysis of trade openness between China and Thailand, and makes qualitative analysis of the impact factors of Sino-Thai trade openness. At last, we make relevant policy recommendations.

From 1975, China and Thailand established formal diplomatic relations to the present, and many domestic and foreign scholars make an in-depth study on the development of trade between China and Thailand. Through the review of related literature, we review the current the study of trade between China and Thailand: The study of Sino-Thai trade development on goods composition of China and Thailand, Shuping Chen and Shuhui Wen (2010) found complementarity in traditional products which based on natural endowments in the two countries [1]. There are convergences, complementary and competitive in the main good. Yanwu Chen and Xiaobing Xie (2013) made the main goods data analysis of China and Thailand from 2005 to 2010 [2]. We got trade features between China and Thailand: competitive and complementary co-exist. Yiyuan Gan (2005) pointed out that China's industrial and subsistence products which are from China to Thailand effectively complemented the goods trading market in Thailand [4]. There are still some factors to influence import and export in Sino-Thai trade. Minghui Su (2016) analyzed the influence factors of Sino-Thai import and export trade, including tariffs, exchange rates, and non-tariff barriers [8].

\footnotetext{
* Corresponding author
} 
Foreign Trade Dependence Degree is regarded as a measure of foreign trade openness, measuring its research methods. Zhige Zhang and Wei Wu (2011) of domestic scholars use Foreign Trade Dependence Degree which is regarded as a comprehensive index to reflect the openness of a country [11]. With the higher the degree of dependence on foreign trade, it can indicate that the world economy has a greater impact on a country's economy. Jianping Peng (2010) [7], Xin Li and Dianqing Xu (2013) used the exchange rate to estimate China's foreign trade dependence, and using purchasing power parity GDP made a correction to China's foreign trade dependence [6]. Rui Xie and Guomei Zhao (2014) used non-competitive input-output table which is a single regional database from WIOT [9]. They presented measuring method of Foreign Trade Dependence Degree, and it based on domestic value added of foreign trade export.

In summary, a large number of scholars have a certain basis on the study of China and Thailand cargo trade openness, but there are still shortcomings. It mainly shows in the following aspects: First, the existing literature mostly focused on the study of China's foreign trade openness, while it is less on trade openness from China to Thailand (or a country). Second, most of the existing literature is more to study service trade from China to Thailand, and less to study cargo trade. Because of above reasons, the article bases on the status of cargo trade from China to Thailand to analyze. By analyzing influence factors which are from China to Thailand on cargo trade openness, we will give the appropriate recommendations and the future trend of development on this basis. These can have a positive effect on trade development from China to Thailand.

\section{The Presnt Situation of The Opening Degree of CARGo TRADE From ChINA TO THALLAND}

Cargo trade opening degree from China to Thailand reflects the degree of market opening. Trade Openness means that China and Thailand will actively participate in the development of trade, and economic ties between the two countries is first formed and developed by cargo trade. Some scholars studied a country's openness to foreign trade by Foreign Trade Dependent Degree, that Foreign Trade Dependent Degree dependence is a ratio which is imports and exports of a country or region and GDP of region or the country, and Foreign Trade Dependent Degree index including export Foreign Trade or Import Dependent Degree. It reflects a relationship between input-output of goods and economic growth in a country or region. It is determined an important indicator of the openness of a country or region. And this article study cargo trade opening degree from China to Thailand, it means the tightness of cargo trade from China to Thailand.

$$
T D=\frac{X_{j}+M_{j}{ }_{j}}{G D} 1000 \%
$$

Equation (1), TD represents cargo trade opening degree from China to Thailand, firstly represents the total value of the exports of the country in the $i$ th year, secondly indicates the total value of imports in the $i$ th year, fourthly $\left(\mathrm{X}_{i}+\mathrm{M}_{i}\right)$ represents bilateral import and export of goods from China to
Thailand in the $i$ th year, at last $\mathrm{GDP}_{i}$ represents GDP of Chinese in the $i$ th year. The greater the ratio will show the greater cargo trade opening degree from China to Thailand.

If you simply used the formula (1) to evaluate cargo trade opening degree from China to Thailand, because the index does not reflect the impact of economies of scale, and it is considerable limitations. In the world we assume that there is only China and Thailand, and each of the national economy is combined with a relatively small number of economic entities. These economic entities are exactly the same, and there are $\mathrm{N}$ $(\mathrm{N}>1)$ in the world [10]. Since China and Thailand are two different national economies, it is combined with a different number of these economic entities. we assume that the Gross domestic product (GDP) of each economic entity is G, and exports of goods to every other economic entities is e, Foreign Trade Dependence Degree dependence of the small economic entity is $\mathrm{i}$, then there is $\mathrm{E}=\mathrm{e}(\mathrm{N}-1)$, for each economic entity to the rest of the total of all goods $(\mathrm{N}-1)$ economic entities exports, namely $\mathrm{i}=\mathrm{E} / \mathrm{G}$. So the Chinese economy of scale is combined with $\mathrm{m}(\mathrm{m}<\mathrm{N})$ economic entities, and the remaining $(\mathrm{N}-\mathrm{m})$ economic entities composes of economies of scale in Thailand, so cargo export dependence from China to Thailand is the formula (2).

Among them, represents a ratio that is Chinese economy accounted for the proportion of Thailand, and it is a mathematical description of Chinese economy of scale. From the above, we can see a decreasing mathematical relation between the traditional foreign trade dependence degree indicators (1) and economies of scale. We can use (1)

$$
\begin{aligned}
& I=\frac{X}{G D P}=\frac{(N-m) * e * m}{m * G} \\
& =\frac{(N-m) * \frac{E}{N-1}}{G}=\frac{N-m}{N-1} * i \\
& =\frac{1-\frac{m}{N}}{1-\frac{1}{N}} * i=\left(1-\frac{m}{M}\right) * i
\end{aligned}
$$

(2) multiplied by a coefficient. The country's Foreign Trade Dependent Degree dependence is a ratio traditional export index multiplied by $1 /(1-\mathrm{m} / \mathrm{N})$, so the result is irrelevant of the national economy scale. In a word, there is irrelevant of the number of national economies of scale (it is $\mathrm{m})$. So if we repaired that traditional Chinese export dependence indicators was $\mathrm{I} 1=\mathrm{K} \times(\mathrm{E} / \mathrm{G})$, where $\mathrm{K}=1 /(1$ GDPC / GDPT) is a correction factor, GDPC represents China's GDP, GDPT represents the sum of the GDP of China and Thailand. This takes into account the different impact of economy scale. Similarly, trade import dependence is also affected by the national economic scale, so the repaired formula is

$$
I_{1}=K * \frac{X_{j}+M_{j}}{G D P_{c}} * 100 \%
$$

With the ratio of the level in the equation (3), it can reflect the influence of cargo trade opening degree from China to Thailand. This article calculates 2005-2014 data which are in 
the Development Indicators from World Bank's World and sorted out (Figure 1).

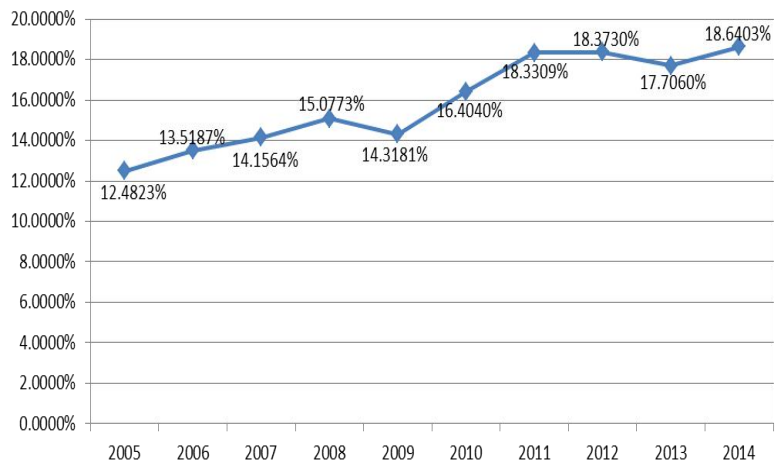

Figure. 1. Index of cargo trade openness from China to Thailand

As we can see from Figure 1, the change of cargo trade opening degree from China to Thailand showed the following characteristics: in 2005-2008, cargo trade opening degree from China to had a upward trend, because <agreement of cargo trade > was signed in November 2004 between China with ASEAN where is covered Thailand. The agreement implements tariff reduction for goods. It reflected the influence on open-door policy of goods and effects from China to Thailand before 2005; in 2008-2009, cargo trade opening degree from China to Thailand had a declined trend. In 2008 cargo trade openness was $15.0773 \%$, but by 2009 it dropped to $14.3181 \%$, which is due to the US subprime mortgage crisis and global financial the outbreak of the crisis in 2008. These crises had a more serious impact on trade between China and Southeast Asia, and they inhibited the trade between China and Thailand; in 2009-2012, there was an increasing trend. To some extent, it reflected the ability of China's economic recovery from the financial crisis, and China promoted economic development of Southeast Asia; in 20122013, there was a declined trend. It is due to took place antigovernment activities in August 2013 in the Thailand, and in November the same year the activities again broke out. To some extent, they affected the trade between China and Thailand; in 2013-2014, cargo trade opening degree showed a rising trend. President Jinping $\mathrm{Xi}$ in Indonesia parliament made an important speech in the October 3 2013. We are willing to build "21st Century Maritime Silk Road" with ASEAN countries". This proposal promoted an increase on cargo trade opening degree from China to Thailand in 20132014.

\section{FACtors AfFecting the CARGo TRADE OpENNESS FROM CHINA TO THAILAND}

Based on the above analysis of the cargo trade openness from China to Thailand, we can see a rising trend in the cargo trade openness from China to Thailand in general. Among them, there are many factors that affect the cargo trade openness from China to Thailand. They have an interaction in these factors, and they form a network with a common link. This article studies the influence factors, which are as follows:

\section{A. The exchange rate of $R M B$ and the Thai Baht}

From the above analysis, it shows import and export of goods and GDP of two countries which are the most direct impact on the factors of the cargo trade openness from China to Thailand. While the exchange rate of the RMB and the Thai Baht will affect trade volume between China and Thailand, and thus it will also affect GDP.

Generally, when the RMB exchange rate declines for the Thai Baht, it is the devaluation of the RMB or undervalued. GDP which is measured by foreign currency (foreign currency is the Thai Baht) is reduced or undervalued, that is to say, the ratio which is Sino-Thai bilateral trade volume and GDP of Chinese will increase; On the contrary, when the exchange rate of RMB increases for the Thai Baht, it is the appreciation of the RMB or overvalued. GDP which is measured by foreign currency (foreign currency is the Thai Baht) is increased or overvalued, that is to say, the ratio which is Sino-Thai bilateral trade volume and GDP of Chinese will reduce; this change will affect the cargo trade openness from China to Thailand. [5]

\section{B. Lower trade facilitation level between China and Thailand}

Trade facilitation is refers to the customs, transport, ecommerce and other fields, to eliminate regulations, procedures, costs, transport regulations and international trade barriers, and to create a simplified, coordinated, transparent and predictable environment for international trade. Although in the January 1, 2010, China and ASEAN signed the China ASEAN Free Trade Area for the development of the expansion of cargo trade between China and Thailand, but there are still some factors that affect cargo trade development between China and Thailand, for example, there may be China - ASEAN free Trade Area tariff system within the opaque phenomenon and the lack of maneuverability; Customs clearance procedures between China and Thailand are complex, cumbersome and inefficient; Scope of market access is strictly limited between China and Thailand; settlement of trade is also complexity between China and Thailand. Overall, the level of trade facilitation is lower between China and Thailand, so it is not conducive to further development of bilateral trade in goods. It will lead to making decline China's openness in Thailand continue to decline of the cargo trade openness from China to Thailand.

\section{Non-tariff barriers}

Because they exist similarity in the industrial structure and more serious homogenization of the export commodities may cause a certain impact on the Thailand or Chinese related industries, countries will use non-tariff barriers to protect domestic industries. For example, Thailand requires imports to provide about food production process and composition of detailed information in the registration of imported food, and the request of public product ingredients and production method is regard as food obstacles from China to Thailand. Especially in the recent three years, cargo trade from China to Thailand has been in deficit, and Thailand in the wake of the financial crisis recovery ability is weak. It will not rule out the possibility of protecting their products after the reduction of tariff barriers in Thailand, which forms a trade barrier. So it 
also will affect the trade openness degree from China to Thailand.

\section{Effect of other factors}

There are some other factors that affect the openness of cargo trade from China to Thailand, such as higher transportation costs and lower efficiency between China and Thailand. At present the Sino-Thai Trade and transportation mainly rely on water transport, but water transport still has a lot of problems which are the inconvenience of shallow waters. Moreover, road transport is the most time consuming in the various modes of transportation, and it is much slower than other modes of transport. This will lead to a decrease in the import and export of cargo trade from China to Thailand.

There are a lot of trade frictions between China and Thailand in the development process, such as anti-dumping and countervailing and so on. In May 17, 2014, Thailand imposed anti-dumping duties on high carbon wire which originated from China, and the tax rate is $5.17-33.98 \%$, for a period of 5 years. These trade frictions will also affect bilateral trade, and lead to lower trade openness.

\section{CONCLUSION}

China and Thailand have been friendly neighbors, and they have a long history of cooperation and trade relations. They are developing countries and they have developed trade each other.so we gives some suggestions on increasing the cargo trade openness from China to Thailand.

\section{A. Expanding complementary goods and weakening competitive goods}

Thailand and China should expand range and scale of complementary goods trade in trade, while we should weaken the competitive goods to increase differences of the bilateral trade. The two countries should optimize bilateral trade commodity structure, and should consider the other side of the market demand and advantages from both sides, to find a suitable class of complementary goods in import and export, and reduce the import and export substitution and competition strong commodity. In the same time, we can also encourage the export commodity which have advantages. To improve the import and export commodity quality and increase high-tech and high added value proportion of trade commodity, two countries should expand the difference of commodity. Whether it is China's exports commodities or Thailand or Thailand's export commodities to the other side of the market to reflect the characteristics of its own, this will lay the foundation for China to increase trade openness of Thailand [3].

\section{B. Improving the level of cargo trade facilitation}

The core strategy "The Belt and Road" is interoperability. China and Thailand should work together to promote the construction of interconnection, and establish the logistics network. It can also build e-commerce platform to promote the cross-border currency settlement system and protect orderly development of cargo trade between China and Thailand. These will improve the level of trade facilitation between
China and Thailand. In the customs, we can set up a special customs clearance window for import and export of goods to China and Thailand, and implement paperless customs clearance procedures to improve customs clearance speed. We can also reduce customs clearance and charges of import and export link. In the infrastructure, we should speed up the construction of roads, railways, waterways, and aviation, so that goods can be freely carried. It will promote the development of cargo trade facilitation.

\section{Cut down the non-tariff barriers}

For direct or indirect non-tariff barriers existing in cargo trade in two countries, it includes the import licenses, import quotas, plant quarantine and so on. The two sides should jointly resolve these problems through communication, negotiation, and so on, in order to achieve a mutually acceptable result. We should enhance mutual trust and slowly eliminate non-tariff barriers to increase cargo trade opening degree from China to Thailand.

\section{ACKNOWLEDGMENT}

This article is finished under my teacher Li Ying of careful supervision. The article is from topic to data collection, and each link is permeated with meticulous care and guidance of the teacher. Next I will make thanks other teachers for helping me. When I wrote the article, I made reference to a number of other scholars about papers and monographs. Major references are listed later in this article. I express my heartfelt thanks to them!

Due to the limitation of my knowledge and experience, although I have thought for many times and modified the original, there may be some omissions and errors. I hope to get criticism from other teachers and the readers.

\section{REFERENCES}

[1] S.P. Chen and S.H. Wen, "Analysis of the commodity structure of SinoThai trade," China Commerce and Trade, 2010, pp. 207-208.

[2] Y.W. Chen and X.B. Xie, "The structure characteristics and prospect of Sino-Thai trade," Journal of Huaqiao University, 2013, pp. 16-22.

[3] J.G. Dai and C.J. Qi, "Trade barriers and countermeasures from China to Southeast Asia on fruit and vegetable: a case study of Indonesia, Malaysia, Thailand, Vietnam, Philippines," Around Southeast Asia, 2008, pp. 44-48.

[4] Y.Y. Gan, X. Huang and Z.H. Ruan, "Analysis of Sino-Thai trade Around Southeast Asia," 2005, pp. 56-60.

[5] T. Li and D.P. Yang, "The impact of RMB exchange rate changes on China's import and export trade," Technology and Management, 2014, pp. 111-115

[6] X. Li and D.Q. Xu, "China's foreign trade dependence degree and reestimate the degree of imbalance-global production chains of added value of trade," Social Sciences of China, 2013, pp. 29-55.

[7] J.P. Peng, "A comparative study of Chinese foreign trade dependence degree under several different accounting methods," Journal of Guangxi University of Finance and Economics, 2010, pp. 101-104.

[8] M.H. Su, "Factors Influencing Sino-Thai Import and Export Trade," Business, 2016, pp. 64-65.

[9] R. Xie and G.M. Zhao, "Effect of export trade on economic growth in China and India," International Economics and Trade Research, 2014, pp. 52-56. 
[10] W. Xie, G.H. Zheng, L. Guo, X.M. Jiang and S.Y. Xu, "Analysis of the influence factors of foreign trade dependence and its calculation correction," Management review, 2006, pp. 57-64
[11] Z.G. Zhang and W. Wu, "Dynamic analysis foreign trade dependence degree of China," International Economics and Trade Research, 2011, pp. 19-26. 